\title{
GAMBARAN KARAKTERISTIK, POLA PENGOBATAN DAN KEPATUHAN PASIEN HIV/AIDS DI KOTA SAMARINDA
}

\author{
Rani Oktavia Claudiaa,", Dewi Rahmawati ${ }^{1,2}$, Jaka Fadraersada ${ }^{1,2}$ \\ ${ }^{1}$ Laboratorium Penelitian dan Pengembangan Kefarmasian "Farmaka Tropis", \\ Fakultas Farmasi, Universitas Mulawarman, Samarinda, Indonesia \\ ${ }^{2}$ Kelompok Bidang Ilmu Farmasi Klinik dan Komunitas, Fakultas Farmasi, \\ Universitas Mulawarman, Samarinda, Indonesia \\ *Email: ranioktaviaclaudia@gmail.com
}

\begin{abstract}
Human Immunodeficiency Virus (HIV) is a virus that attacks the immune system and weakens the body's defense system against infection. Acquired Immune Deficiency Syndrome (AIDS) is a disease characterized by one or more indicator diseases with no other causes than immunodeficiency. This study aims to determine the characteristics, patterns of treatment, and patient adherence to HIV/AIDS in Samarinda City. The method used was observational conducted prospectively using data collection book and Morisky Medication Adherence Scale (MMAS) questionnaire. Data collection was carried out from July to November 2018. This study used quantitative descriptive analysis to describe the data obtained. The results of patient characteristics the most gender is men 16 (53.34\%), the most age is 26-35 years old $13(43.34 \%)$, the most type of work is private sector 12 (40\%), the most transmission method is sexual relations with men (homosexual and heterosexual) 15 (50\%), the most stage of HIV / AIDS is stage I 20 (66,67\%). Based on treatment pattern data most applied therapy in HIV/AIDS patients is Triple FDC 26 (86,67\%). Based on MMAS questionnaire, 16 (53,43\%) HIV/AIDS patients have moderate compliance.
\end{abstract}

Keywords: Characteristics, Compliance, HIV / AIDS, MMAS, Treatment Pattern

\begin{abstract}
ABSTRAK
Human Immunodeficiency Virus (HIV) adalah virus yang menyerang sistem kekebalan dan melemahkan sistem pertahanan tubuh terhadap infeksi. Acquired Immuno Deficiency Syndrome (AIDS) adalah penyakit yang ditandai dengan satu atau lebih penyakit indikator dengan tidak ada penyebab lain selain immunodeficiency. Penelitian ini bertujuan untuk mengetahui karakteristik, pola pengobatan, dan kepatuhan pasien HIV/AIDS di Kota Samarinda. Metode yang digunakan adalah observasional yang dilakukan secara prospektif dengan menggunakan lembar pengumpul data dan kuisoner Morisky Medication Adherence Scale (MMAS). Pengambilan data dilakukan dari bulan Juli-November 2018. Penelitian ini menggunakan analisis deskriptif kuantitatif untuk memaparkan data yang didapatkan Hasil penelitian karakteristik pasien berdasarkan jenis kelamin terbanyak adalah laki-laki $16(53,34 \%)$, umur terbanyak adalah 26-35 tahun 13
\end{abstract}


$(43,34 \%)$, jenis pekerjaan terbanyak adalah swasta $12(40 \%)$, cara penularan terbanyak adalah hubungan seksual dengan lelaki (homoseksual dan heteroseksual) 15 (50\%), stadium HIV/AIDS terbanyak adalah stadium I 20 (66,67\%). Berdasarkan data pola pengobatan terapi yang paling banyak digunakan pada pasien HIV/AIDS adalah Triple FDC 26 (86,67\%). Berdasarkan kuisoner MMAS sebanyak $16(53,34 \%)$ pasien HIV/AIDS memiliki Kepatuhan Sedang.

Kata kunci : HIV/AIDS, Karakteristik, Kepatuhan, MMAS, Pola Pengobatan

DOI: https://doi.org/10.25026/mpc.v8i1.311

\section{PENDAHULUAN}

Pada tahun 2015 diperkirakan terdapat 36,7 juta (34 juta-39,8 juta) orang hidup dengan HIV, meningkat sebanyak 3,4 juta dibandingkan tahun 2010. Sebanyak 2,1 juta diantaranya merupakan kasus baru HIV. Namun, dalam laporan yang sama terjadi penurunan kematian, WHO mencatat sejak AIDS ditemukan hingga akhir 2015 terdapat 34 juta orang meninggal dan ditahun 2015 tercatat sebesar 1,1 juta orang meninggal terkait dengan AIDS[1].

Pravalensi HIV/AIDS di

Indonesia masih menjadi masalah kesehatan utama. Hingga saat ini HIV/AIDS sudah menyebar di 390 dari 498 kabupaten atau kota di seluruh provinsi di Indonesia. Sejak dilaporkan sampai dengan tahun 2005 (859 kasus), hingga dengan 2016 (41.250 kasus). Dari bulan Januari sampai Maret 2017 jumlah infeksi HIV dilaporkan sebanyak 10.376 orang. Persentase infeksi tertinggi pada kelompok umur 25-49 tahun $(69,6 \%)$, diikuti kelompok umur 20-24 tahun $(17,6 \%)$ dan kelompok umur $\geq 50$ tahun $(6,7 \%)$. Persentase faktor risiko HIV tertinggi adalah hubungan seks berisiko pada heteroseksual (24\%), LSL (Lelaki Seks Lelaki) (28\%) dan penggunaan jarum suntik tidak steril penasun(napza) (2\%). Sedangkan pada jumlah AIDS dilaporkan sebanyak 673 orang[2].

Sistem imun merupakan mekanisme pertahanan tubuh sebagai pelindung dari bahaya berbagai bahan dalam lingkungan yang dianggap asing bagi tubuh seperti bakteri, virus, jamur, parasit, dan protozoa[3]. Human Immunodeficiency Virus (HIV) adalah virus yang menyerang sistem kekebalan dan melemahkan sistem pertahanan tubuh terhadap infeksi. Virus ini menyerang dan merusak fungsi sel-sel pertahanan tubuh, sehingga imunitas tubuh akan terus menurun secara progresif[4].

\section{Acquired Immuno Deficiency} Syndrome (AIDS) adalah penyakit yang ditandai dengan satu atau lebih penyakit indikator dengan tidak ada penyebab lain selain immunodeficiency. Indikator tersebut adalah infeksi oportunistik[5]. Penderita HIV/AIDS memerlukan pengobatan dengan ARV untuk menurunkan jumlah virus HIV didalam tubuh agar tidak masuk kedalam stadium AIDS. Pasien yang mendapat pengobatan, harus patuh dalam mengkonsumsi obat ARV seumur hidup, tepat waktu dan disiplin.

Kepatuhan merupakan salah satu indikator keberhasilan ARV. Kepatuhan dan kesinambungan berobat lebih menitikberatkan pada peran dan kesadaran pasien (bukan hanya mengikuti perintah dokter), dengan dibantu dokter atau petugas kesehatan, pendamping dan ketersediaan obat[6].

Pasien HIV/AIDS harus patuh terhadap terapi ARV salah satu 
penyebabnya adalah untuk mencegah penurunan limfosit CD4 dan menurunkan jumlah HIV didalam tubuh sehingga mengurangi resiko terjadinya infeksi oportunistik dan dapat meningkatkan kualitas hidup pasien HIV/AIDS. Cara terbaik untuk mencegah perkembangan resistensi adalah dengan patuh menggunakan terapi [7].

\section{METODE}

Penelitian ini dilakukan pada bulan Juli-November 2018 di RSUD Abdul Wahab Sjahranie Samarinda. Metode yang digunakan adalah observasional yang dilakukan secara prospektif menggunakan lembar pengumpul data untuk mengetahui karakteristik dan pola pengobatan dan kuisoner Morisky Medication Adherence Scale (MMAS) untuk mengetahui kepatuhan pasien HIV/AIDS. Dengan pengambilan sampel secara Cluster sampling. Jenis penelitian yang dilakukan adalah penelitian kuantitatif yang akan dipaparkan secara deskriptif untuk melihat karakteristik, pola pengobatan, dan kepatuhan.

Tabel 1. Karakteristik pasien HIV/AIDS

\begin{tabular}{|c|c|c|}
\hline Karakteristik & Jumlah & $\%$ \\
\hline \multicolumn{3}{|l|}{ Jenis Kelamin } \\
\hline Laki-laki & 16 & 53,34 \\
\hline Perempuan & 14 & 46,67 \\
\hline \multicolumn{3}{|l|}{ Umur } \\
\hline 18-25 tahun & 5 & 16,67 \\
\hline 26-35 tahun & 13 & 43,34 \\
\hline 36-45 tahun & 7 & 23,34 \\
\hline 46-55 tahun & 5 & 16,67 \\
\hline \multicolumn{3}{|l|}{ Pekerjaan } \\
\hline Swasta & 12 & 40 \\
\hline Ibu Rumah Tangga & 11 & 36,67 \\
\hline Wirausaha & 3 & 10 \\
\hline Guru & 1 & 3,34 \\
\hline PNS & 1 & 3,34 \\
\hline Pendukung Sebaya & 2 & 6,67 \\
\hline \multicolumn{3}{|l|}{ Cara Penularan } \\
\hline $\begin{array}{l}\text { Hubungan seksual dengan lelaki } \\
\text { (Homoseksual dan Heteroseksual) }\end{array}$ & 15 & 50 \\
\hline Hubungan seksual dengan perempuan & 5 & 16,67 \\
\hline Obat-obatan suntik & 4 & 13,34 \\
\hline Lainnya/Tidak tahu & 6 & 20 \\
\hline \multicolumn{3}{|l|}{ Stadium HIV } \\
\hline Stadium I & 20 & 66,67 \\
\hline Stadium II & 7 & 23,34 \\
\hline Stadium III & 3 & 10 \\
\hline Total & 30 & 100 \\
\hline
\end{tabular}

Tabel 2. Pola Pengobatan

\begin{tabular}{lcc}
\hline \multicolumn{1}{c}{ Pola Pengobatan } & Jumlah & $\%$ \\
\hline Triple FDC & 26 & 86,67 \\
Efavirenz, Lamivudin, Zidovudin & 3 & 10 \\
Zidovudin, Lamivudin, Nevirapin & 1 & 3,34 \\
\hline Total & 30 & 100 \\
\hline
\end{tabular}




\section{HASIL DAN PEMBAHASAN}

\section{Karakteristik}

Berdasarkan jenis kelamin pasien HIV/AIDS terbanyak adalah laki-laki sebanyak 16 orang $(53,43 \%)$. Kerentanan laki-laki terhadap infeksi HIV/AIDS disebabkan oleh perilaku negatif yang dilakukan seperti membeli jasa seks komersial, laki-laki mempunyai mobilitas tinggi dan jauh dari pasangan. Menurut data Ditjen PP dan PL Kemenkes RI 2017 jumlah laki-laki lebih banyak terinfeksi HIV dibandingkan perempuan dan terjadi peningkatan pada populasi laki-laki melakukan hubungan seksual dengan laki-laki pada tahun 2010 sebesar 506 dan tahun 2016 sebesar 13.063[2]

Berdasarkan umur pasien HIV/AIDS paling banyak pada umur 2635 tahun sebanyak 13 (43,34\%), dimana pada umur 26-35 tahun merupakan kelompok umur yang memang rentan terinfeksi HIV/AIDS karena kelompok umur tersebut masuk kedalam kelompok umur produktif yang aktif secara seksual. Dari segi umur masuk dalam perkembangan masa dewasa dini (early adulthood) yaitu pada umur 26-35 tahun masa dewasa dini selalu dianggap sebagai penyesuaian diri terhadap kehidupan dan harapan sosial baru, sehingga dapat menyebabkan seseorang ingin melakukan hal-hal baru inilah yang menyebabkan pergaulan bebas[8].

Berdasarkan jenis pekerjaan pasien yang terbanyak yaitu swasta sebanyak 12 (40\%). Hal ini dikarenakan pekerjaan swasta tidak lepas dari perilaku beresiko pada laki-laki yang memiliki mobilitas diluar rumah tinggi sehingga banyak faktor yang bisa mempengaruhi mereka untuk melakukan perilaku seksual berisiko atau seksual komersial. Ibu rumah tangga juga memiliki persentase cukup besar yaitu $11(36,67)$, namun itu merupakan dampak dari sebagian suami yang memiliki kebiasaan buruk dan berisiko terhadap penyakit HIV/AIDS[9]. Berdasarkan cara penularan pasien yang terbanyak yaitu hubungan seksual dengan lelaki (homoseksual dan heteroseksual) sebanyak 15 (50\%). Hal ini disebabkan karena hubungan seksual dengan lelaki melalui anal (anal intercourse) yang banyak dilakukan LSL merupakan teknik hubungan seks yang paling berisiko menularkan HIV/AIDS. Hal ini dikarenakan anus tidak didesain untuk berhubungan seksual sehingga akan mengalami perlukaan saat melakukan anal seks dan memudahkan masuknya HIV kedalam tubuh[10].

Berdasarkan Stadium HIV/AIDS menunjukkan bahwa pasien yang terbanyak yaitu Stadium I sebanyak 20 $(66,67 \%)$. Stadium I adalah infeksi HIV asimtomatik dan tidak dikategorikan AIDS. Pada tahap ini, pengidap HIV akan terlihat normal seperti orang sehat biasa pada umunya, sehingga banyak yang tidak menyadari bahwa mereka terinfeksi oleh virus HIV. Periode tanpa gejala dapat terjadi bertahun-tahun. Pada stadium ini penderita tidak menunjukkan gejala dan kalau ada berupa pembesaran kelenjar getah bening diberbagai bagian tubuh penderita misalnya leher, ketiak dan lipatan paha. Dimana pada stadium ini masih dapat ditangani dengan menggunakan obat-obatan ARV untuk menekan penyebaran virus sehingga dapat mencegah stadium selanjutnya muncul[11]. Adanya kesadaran dari pasien untuk memeriksakan diri setelah melakukan hubungan beresiko atau pemeriksaan yang tidak sengaja seperti pasien akan melakukan operasi dan melakukan pemeriksaan menyeluruh sehingga diketahui terinfeksi HIV. Dimana pasien HIV/AIDS harus melakukan pemeriksaan CD4 atau Viral load karena untuk pasien HIV/AIDS stadium I mulai mendapatkan terapi jika jumlah CD4 $<300 \mathrm{sel} / \mathrm{mm}^{3}[12]$. 
Tabel 3. Tingkat Kepatuhan

\begin{tabular}{lccc}
\hline Tingkat Kepatuhan & Skor & Jumlah & $\%$ \\
\hline Kepatuhan Tinggi & 8 & 12 & 40 \\
Kepatuhan Sedang & $6-<8$ & 16 & 53,34 \\
Kepatuhan Rendah & $<6$ & 2 & 6,67 \\
\hline Total & & 30 & 100 \\
\hline
\end{tabular}

\section{Data Pola Pengobatan}

Hasil pola pengobatan pasien HIV/AIDS dapat dilihat pada tabel 2 . Berdasarkan tabel tersebut dapat diketahui pola pengobatan pasien HIV/AIDS yang terbanyak yang digunakan adalah Tripel FDC sebanyak $26(86,67 \%)$.

Berdasarkan hasil penelitian menunjukkan bahwa pola pengobatan pasien HIV/AIDS yang terbanyak yang digunakan adalah Triple FDC sebanyak $26(86,67 \%)$. Hal ini dikarenakan Triple FDC merupakan jenis Fixed Dose Combination yang cukup diminum satu kali pakai pada malam hari menjelang tidur. Obat ini berisi kandungan 3 bahan aktif yaitu Tenofovir, Lamivudin dan Efavirenz dan termasuk dalam paduan ARV lini pertama yaitu 2 NRTI + 1 NNRTI. Dimana NRTI (Nucleosida Reserve Transcriptase Inhibitors) berkompetisi dengan natural nukleotida menghambat reverse transcriptase sehingga perubahan RNA menjadi DNA terhambat sedangkan NNRTI (Nonnucleoside Reserve Transcriptase Inhibitor) bekerja dengan mengganggu proses penciptaan DNA virus dari RNA dengan mengikat enzim reserve transcriptase. Triple FDC juga mempunyai tingkat racun yang rendah bagi tubuh serta memiliki efek samping yang rendah[13]. Pemberian Triple FDC efektif dalam meningkatan kadar CD4 yaitu $75,69 \mathrm{sel} / \mathrm{mm}^{3}$ dibandingkan dengan kombinasi lain seperti Efavirenz, Lamivudin dan Zidovudin yaitu 65,12 $\mathrm{sel} / \mathrm{mm}^{3}[14]$.

\section{Data Kepatuhan Pasien HIV/AIDS}

Hasil Kepatuhan Pasien HIV/AIDS dapat dilihat pada tabel 3 . Berdasarkan tabel tersebut dapat diketahui kepatuhan pasien HIV/AIDS yang menjalankan pengobatan memiliki Kepatuhan Sedang yaitu sebanyak 16 $(53,34 \%)$.

Berdasarkan hasil penelitian menunjukkan bahwa kepatuhan pasien HIV/AIDS yang menjalankan pengobatan memiliki Kepatuhan Sedang yaitu sebanyak $16 \quad(53,34 \%)$. Hal ini disebabkan karena kurangnya kesadaran pasien HIV/AIDS terhadap pentingnya meminum obat secara rutin, karena dampak dari lupa atau tidak sama sekali meminum obat sangat besar terhadap kondisi kesehatan. Pasien yang memiliki kepatuhan sedang pada saat mengisi kuisoner MMAS mayoritas kadangkadang atau sesekali lupa meminum obat ARV nya. Pasien HIV/AIDS harus patuh terhadap terapi ARV salah satu penyebabnya adalah untuk mencegah penurunan limfosit CD4 dan menurunkan jumlah virus HIV didalam tubuh sehingga mengurangi terjadinya infeksi oportunistik[7].

Adanya terapi ARV ini diharapkan dapat mengurangi laju penularan, menurunkan angka morbiditas dan mortalitas, memperbaiki kualitas hidup, memulihkan dan memelihara fungsi kekebalan tubuh, dan menekan replikasi virus semaksimal mungkin[15]. Keberadaan keluarga (suami/istri, anak dan orang tua) sebagai Pengawas Minum Obat (PMO) serta dukungan teman sebaya merupakan salah satu faktor penting terhadap kepatuhan minum obat 
ARV. Pengawas Minum Obat (PMO) diwajibkan untuk datang ketika pasien pertama kali memulai ARV dan menemani pasien konseling. Selain itu, pasien memanfaatkan teknologi alarm sebagai pengingat minum obat [16].

\section{KESIMPULAN}

Hasil penelitian karakteristik pasien berdasarkan jenis kelamin laki-laki sebanyak $16(53,34 \%)$, berdasarkan umur pasien paling banyak pada umur 26-35 tahun sebanyak 13 (43,34\%), berdasarkan jenis pekerjaan pasien yang terbanyak yaitu swasta sebanyak 12 $(40 \%)$, berdasarkan cara penularan yang terjadi pada pasien yang terbanyak yaitu pada hubungan seksual dengan lelaki (homoseksual dan heteroseksual) sebanyak 15 (50\%), berdasarkan stadium HIV/AIDS pasien yang terbanyak yaitu stadium I sebanyak $20 \quad(66,67 \%)$. Berdasarkan data pola pengobatan pola pasien HIV/AIDS yang terbanyak yang digunakan adalah Tripel FDC sebanyak $26(86,67 \%)$. Berdasarkan data kepatuhan pasien HIV/AIDS yang menjalankan pengobatan memiliki Kepatuhan Sedang yaitu sebanyak $16(53,34 \%)$.

\section{DAFTAR PUSTAKA}

[1] Kementrian kesehatan RI. 2015. Situasi Penyakit HIV/AIDS di Indonesia. INFODATIN Pusat Data dan Informasi Kementrian Kesehatan RI

[2] Ditjen PP dan PL Kemenkes RI. 2017. Statistik kasus HIV/ AIDS di Indonesia. Kemenkes RI. Jakarta

[3] Abbas, A.K., Lichtman, A.H and Pillai, S. 2015. Celluler and Molecular Eighth Edition. Elsevier, Saunders. Philadelphia

[4] World Health Organization. 2011. The World Medicine Situation 3ed. Rational Use of Medicine. Geneva

[5] Williams, D and Lewis, M. 2011. Patogenesis and Treatment of Oral Candidosis. Journal of Oral Microbiology Vol.3
[6] Kemenkes RI. 2011. Pedoman Nasional Tatalaksana Klinis Infeksi HIV dan Terapi Antiretroviral Pada Orang Dewasa. Kementrian Kesehatan Republik Indonesia. Jakarta

[7] Djauzi S dan Djoerban Z. 2007. HIV/AIDS di Indonesia. Pusat Penerbitan Departemen Ilmu Penyakit Dalam FKUI. Jakarta

[8] Pieter,H.Z \& Lubis,N.L. 2010. Pengantar Psikologi Dalam Keperawatan. Kencana. Jakarta

[9] Nandasari Fufa. 2015. Identifikasi Perilaku Seksual dan Kejadian HIV (Human Immunodeficiency Virus) pada Sopir Angkutan Umum di Kabupaten Sidoarjo. Jurnal Berkala Epidemiologi, Vol 3, No 1.

[10] Sidjabat, Forman N. 2017. Lelaki Seks Lelaki HIV/AIDS dan Perilaku Seksualnya di Semarang. Jurnal Kesehatan Reproduksi 8(2) 131-142

[11]Rasmaliah and Hutapea, D. M., Sarumpaet, S. M. 2013. Karakteristik Penderita HIV/AIDS di Klinik VCT Rumah Sakit Umum HKBP Balige Tahun 2008 - 2012. Jurnal Gizi, Kesehatan Reproduksi dan Epidemiologi Vol 2, No 6

[12]Ditjen P2PL. 2011. Pedoman Nasional Tatalaksana Klinis Infeksi HIV dan Terapi Antiretroviral pada Orang Dewasa. Kementrian Kesehatan RI. Jakarta

[13]Departemen Kesehatan RI. 2006. Pedoman Pelayanan Kefarmasian untuk Orang dengan HIV/AIDS (ODHA). Direktorat Bina Farmasi Komunitas dan Klinik. Ditjen Bina Kefarmasian dan Alat Kesehatan. Jakarta

[14] Manggau. 2015. Effectiveness of Tenofovir (TDF)/Emtricitabine (FTC) Versus Zidovudine (AZT)/ Lamivudine (3TC) in Combination with Efavirenz (EFV) IN Antiretroviral-Naive HIV-Infected Patients IN Eritrea. International 
Journal of Pharmaceutical and Clinical Research 7(5): 364-367

[15]Ditjen PP dan PL Depkes RI. 2011. Pedoman Nasional Tatalaksana Klinis Infeksi HIV dan Terapi Antiretroviral pada Orang Dewasa. Depkes RI. Jakarta
[16]Noerliani, D. 2016. Faktor-faktor Pendukung Orang dengan HIV/AIDS (ODHA) dalam Minum Obat Antiretroviral. Jurnal Keperawatan Madiun 3(1) 